\title{
Identyfikacja i znaczenie krążących endotelialnych komórek progenitorowych u chorych na raka wątrobowokomórkowego
}

\author{
Włodzimierz Otto ${ }^{1}$, Maria Król2 ${ }^{2}$, Maciej Maciaszczyk ${ }^{3}$, \\ Janusz Sierdziński ${ }^{4}$, Bogusław Najnigier ${ }^{1}$, Marek Krawczyk ${ }^{1}$
}

Cel badań. Badania poświęcono identyfikacji i ocenie znaczenia endotelialnych komórek progenitorowych we krwi obwodowej chorych na HCC.

Materiał i metoda. Badania przeprowadzono u 133 chorych na HCC, dotychczas nieleczonych, z których 46 zostało zakwalifikowanych do resekcji wątroby, 45 do przeszczepienia wątroby i 42 do leczenia paliatywnego. Grupę kontrolną stanowiło 43 osób zdrowych i 42 chorych na marskość wątroby, bez stwierdzonego raka. Od badanych pobierano próbki świeżej krwi w objętości 2 ml i niezwłocznie wykonywano badanie fenotypu komórek metodą cytometrii przepływowej z użyciem cytometru FACS CANTO II. Frakcję endotelialnych komórek progenitorowych (EPCs) o fenotypie CD34(+)CD133(+)CD45(dim)CD309(+) identyfikowano za pomocą wymienionych markerów powierzchniowych. Populację hematopoetycznych komórek macierzystych (HSCs) identyfikowano na podstawie fenotypu CD34(+) CD133+)CD45(dim), zgodnie z regułami ISHAGE. Wyniki, przedstawione jako odsetek endotelialnych komórek progenitorowych w populacji hematopoetycznych komórek macierzystych (\%EPCs/HSCs) oraz odsetek HSCs w puli leukocytów CD45(+) (\%HSCs/WBC) opracowano statystycznie.

Wyniki. Badanie wykazało znamienne różnice we frakcji EPCs i subpopulacji HSCs pomiędzy chorymi na raka i osobami zdrowymi (test U Manna-Whitneya: chisq $=-5,92 ; p<0,0001$ i chisq 3,85; $p<0,0001$, odpowiednio) oraz pomiędzy chorymi na raka i na marskość wątroby (chisq = -6,09; $p<0,0001$ i 2,47; $p<0,01$, odpowiednio). Różnice te nie były znamienne pomiędzy chorymi na HCC a chorymi na marskość wątroby (NS).

Wnioski. Wzrost odsetka hematopoetycznych komórek macierzystych i ich frakcji, endotelialnych komórek progenitorowych, wskazuje na rolę, jaką odgrywają w rozwoju raka wątrobowokomórkowego. Nieistotne różnice pomiędzy chorymi na raka i na marskość wątroby potwierdzają tezę o przedrakowym charakterze marskości.

\section{Identification and significance of circulating endothelial progenitor cells in patients with hepatocellular carcinoma}

Aim of study. The study identified and assessed the role of endothelial progenitor cells in the peripheral blood circulation of patients with hepatocellular carcinoma.

Material and methods. There were $133 \mathrm{HCC}$ patients who qualified for liver resection, 45 for liver transplantation, and 42 for palliation. Control groups consisted of 43 healthy and 42 cirrhotic individuals. Circulating HSCs and EPCs were measured by phenotypic analysis of fresh blood samples in a flow cytometer according to the approval of ISHAGE.

\footnotetext{
${ }^{1}$ Katedra i Klinika Chirurgii Ogólnej, Transplantacyjnej i Wątroby Warszawski Uniwersytet Medyczny

${ }^{2}$ Katedra i Klinika Hematologii, Onkologii i Chorób Wewnętrznych Warszawski Uniwersytet Medyczny

${ }^{3}$ Instytut Gruźlicy i Chorób Płuc w Rabce

${ }^{4}$ Zakład Informatyki Medycznej i Telemedycyny

Warszawski Uniwersytet Medyczny
} 
Endothelial progenitor cells (EPCs) were defined and enumerated as CD34(+),133(+),CD45(dim), CD309(+). Results were evaluated statistically indicating the rate of endothelial progenitor cells (\%EPCs) in the fraction of hematopoietic stem cells (HSCs - defined as CD34(+),CD133(+),CD45(dim), the subpopulation of leukocytes (WBC) - defined as CD45(+) cells.

Results. Significant differences were found in the rate of the EPC fraction and in the HSC subpopulation between cancer patients and healthy individuals (the test used was U-Mann-Whitney: Chisq $=-5.92, p<0.0001$ and Chisq $=3.85$, $p<0.0001$, respectively), and between patients with cirrhosis and with a healthy liver (Chisq $=-6.09, p<0.0001$ and Chisq $=2.47, \mathrm{p}<0.01$, respectively). The differences between patients with $\mathrm{HCC}$ and with liver cirrhosis were statistically not significant.

Conclusions. Increasing the rate of hematopoietic stem cells and endothelial progenitor cells in peripheral blood circulation indicates the importance for HCC development.

NOWOTWORY Journal of Oncology 2013; 63, 5: 383-394

Słowa kluczowe: endotelialne komórki progenitorowe, rak wątrobowokomórkowy

Key words: endothelial progenitor cells, hepatocellular carcinoma

\section{Wstęp}

Rak wątrobowokomórkowy (hepatocellular carcinoma - HCC) jest procesem ogólnoustrojowym, często wieloogniskowym. U większości chorych rozwija się na podłożu pozapalnej lub poalkoholowej marskości wątroby [1-5]. Zagadnienia związane z jego wykrywalnością, diagnostyką i leczeniem stanowią jedno z najpoważniejszych wyzwań i problemów współczesnej medycyny. W Klinice Chirurgii Ogólnej, Transplantacyjnej i Wątroby Uniwersytetu Medycznego w Warszawie każdego roku leczonych jest średnio 150 chorych na raka wątrobowokomórkowego. W latach 2009-2012 było ich łącznie 677 i niemal w 80\% przypadków byli to chorzy na marskość wątroby i na nadciśnienie wrotne. W tym okresie na ogólną liczbę 585 przeprowadzonych w Klinice przeszczepień wątroby w 84 przypadkach transplantację wykonano u chorych na HCC. Obok resekcji wątroby była to podstawowa metoda operacyjnego leczenia raka wątrobowokomórkowego. Decyzję o wyborze sposobu leczenia operacyjnego podejmowano na podstawie odpowiednich systemów oceny klinicznej, przede wszystkim klasyfikacji Childa-Pugha, BCLC (Barcelona Clinic Liver Cancer) i kryteriów mediolańskich. Umożliwiają one wskazanie chorych, którzy spełniają kryteria pod względem zaawansowania guza i wydolności wątroby i rokują podjęcie radykalnego leczenia chirurgicznego. Wymienione klasyfikacje nie oddają jednak w pełni relacji pomiędzy właściwościami guza, ryzykiem nawrotu choroby i okresem przeżycia. Skłania to do poszukiwania nowej skali ocen i opracowania wskaźników, które ułatwiłyby wybór sposobu leczenia i poprawiłyby trafność przewidywania jego skutków [4-8].

Jedną z charakterystycznych właściwości raka wątrobowokomórkowego jest zdolność angiogenezy, tj. nowotworzenia naczyń krwionośnych i wysoce rozwiniętego patologicznego ukrwienia tętniczego, które "rośnie” wraz z rozwojem guza. Rak wrasta do światła naczyń wrotnych, tworząc skrzepliny w rozgałęzieniach wewnątrzwątrobowych oraz w pniu żyły wrotnej. Mechanizm angiogenezy jest prawdopodobnie jedną z istotnych przyczyn gwałtownego, ekspansywnego i ogólnoustrojowego charakteru choroby, tworzenia przez nowotwór wcześnie przerzutów odległych i wznowy procesu nawet po tak radykalnym leczeniu chirurgicznym, jak rozległa resekcja lub przeszczepienie wątroby. Badania podstawowe prowadzone w wielu ośrodkach potwierdzają znaczenie, jakie w rozwoju tego nowotworu złośliwego odgrywa proces tworzenia nowego, patologicznego ukrwienia tętniczego [8-13]. Duże znaczenie dla angiogenezy w procesie rozwoju HCC mają prawdopodobnie endotelialne komórki progenitorowe (endothelial progenitor cells - EP(s), frakcja hematopoetycznych komórek macierzystych o fenotypie CD34(+)CD133(+) CD45(dim), które powstają zarówno w procesie naturalnej hematopoezy, jak też uwalniane są ze szpiku kostnego pod wpływem cytokin nowotworowych, między innymi VEGF (vascular endothelial growth factor). Komórki te, poza dodatnią reakcją z przeciwciałami wymienionymi powyżej, wskazującymi na ich macierzysty charakter, cechuje obecność powierzchownego receptora VEGFR-2 (KDR), a zatem pozytywna reakcja z przeciwciałem monoklonalnym anty-CD309 (VEGFR-2, KDR). Przyjmuje się, że wyrazem aktywności angiogenezy nowotworowej w HCC jest wzrost odsetka endotelialnych komórek progenitorowych we krwi obwodowej [11-19, 25].

Złożoność mechanizmów angiogenezy nowotworowej uzasadnia poznawcze i praktyczne cele prowadzonych badań. Jednym z obiecujących kierunków badań jest opracowanie inhibitorów kinaz nowotworowych i receptorów VEGF oraz wprowadzenie celowanej terapii antyangiogennej w zaawansowanych postaciach HCC. Innym jest poznanie czynników wpływających na proliferację guza nowotworowego oraz poszukiwanie czynników prognostycznych i markerów diagnostycznych, umożliwiających lepszą ocenę 
i kwalifikację chorych do leczenia zabiegowego i skojarzonego. Badania prowadzone w Klinice dostarczyły istotnych informacji dotyczących aktywności endotelialnych komórek progenitorowych w krążeniu obwodowym chorych na HCC i korelacji pomiędzy liczbą endotelialnych komórek progenitorowych a cechami oraz obrazem klinicznym nowotworu. Poszerzyły tym samym skalę klinicznej oceny chorych na raka wątrobowokomórkowego kwalifikowanych do resekcji i transplantacji wątroby.

\section{Materiał}

Badania identyfikacji i oceny liczby endotelialnych komórek progenitorowych przeprowadzone zostały u 133 chorych leczonych z powodu raka wątrobowokomórkowego w latach 2009-2013 w Katedrze i Klinice Chirurgii Ogólnej, Transplantacyjnej i Wątroby Samodzielnego Publicznego Centralnego Szpitala Klinicznego, WUM w Warszawie przy ul. Banacha $1 \mathrm{a}$.

Wśród chorych na raka wątrobowokomórkowego (grupa 1) wyróżniono grupę leczonych resekcją wątroby (grupa 1-A), grupę leczonych transplantacją wątroby (grupa 1-B) i grupę leczonych metodami niechirurgicznymi (grupa 1-C). Grupę kontrolną stanowiło 42 chorych na marskość wątroby, lecz bez stwierdzonego raka wątrobowokomórkowego (grupa 2) oraz 43 pacjentów mających wątrobę zdrową (grupa 3). Na podstawie analizy mocy liczebność każdej z grup badanych i grup kontrolnych ustalono na minimum 42 osoby, wyznaczając liczebność próby jako funkcję testu (a priori power analysis) i zakładając, że częstość występowania endotelialnych komórek progenitorowych (EPCs) we krwi obwodowej osób zdrowych wynosi 0-2500/ml, przy oczekiwanym poziomie znamienności statystycznej $\alpha$ poniżej 0,05.

Rozpoznanie kliniczne, a także ocena stopnia wydolności wątroby i ocena stopnia zaawansowania raka u chorych na raka wątrobowokomórkowego nastąpiły na podstawie obrazu klinicznego, badań laboratoryjnych - morfologii krwi, poziomu albumin, bilirubiny, aktywności transaminaz, fosfatazy zasadowej (AFP), czynników układu krzepnięcia, poziomu alfa-fetoproteiny (AFP) w surowicy krwi oraz badań obrazowych - ultrasonografii (USG i USG Doppler), spiralnej tomografii komputerowej (TK) i rezonansu magnetycznego (MR).

Do badania włączeni zostali chorzy w wieku poniżej 75 roku życia, niezależnie od płci, którzy do chwili rozpoznania HCC nie przebyli leczenia chemioterapią lub innego leczenia przeciwnowotworowego.

Do grupy 1-A zakwalifikowano 46 chorych, u których rozpoznano pojedynczy guz w stopniu zaawansowania klinicznego A1-A4 wg oceny BCLC (Barcelona Clinic Liver Cancer) lub Okuda I, w okresie wydolności wątroby (wątroba zdrowa lub wątroba marska w grupie wydolności A wg Childe'a), kwalifikujący chorego do wykonania resekcji wątroby.
Do grupy 1-B zakwalifikowano 45 chorych, u których rozpoznano pojedynczy guz wielkości $<5 \mathrm{~cm}$ lub 3 guzy o średnicy $<3 \mathrm{~cm}$ (tj. spełniający kryteria mediolańskie), w stopniu zaawansowania klinicznego A/B wg oceny BCLC (Barcelona Clinic Liver Cancer) lub Okuda I/II, w okresie wydolności wątroby (wątroba zdrowa lub wątroba marska w grupie wydolności A/B wg Childe'a), kwalifikujący chorego do wykonania transplantacji wątroby.

Do grupy 1-C zakwalifikowano 42 chorych, u których rozpoznano zaawansowanego raka w wątrobie zdrowej lub zmienionej marsko (ocena wg kryteriów mediolańskich, klasyfikacji BCLC i Okuda), niezależnie od przyczyny wywołującej marskość wątroby, u których stan choroby nowotworowej nie kwalifikował do leczenia chirurgicznego.

Z udziału w badaniu wyłączeni zostali chorzy w wieku powyżej 75 lat oraz chorzy, u których rozpoznano współistnienie choroby niedokrwiennej serca, objawy zaawansowanej choroby wieńcowej i przebytego zawału serca, przebytego rozległego oparzenia ciała, choroby niedokrwiennej kończyn dolnych na tle zapalenia naczyń i miażdżycy lub innej patologii, także patologii pozawątrobowej, której stan zaawansowania wykluczałby leczenie operacyjne. Z badania wykluczeni zostali także chorzy, którzy przebyli w okresie poprzedzającym chemioterapię leczenie lekami hamującymi angiogenezę, leczenie statynami lub terapię genową.

Grupę kontrolną stanowiło 85 osób; 42 chorych na marskość wątroby, niezależnie od przyczyny wywołującej marskość, lecz bez stwierdzonego raka i przyjętych w celu kwalifikacji do przeszczepienia wątroby (kontrola negatywna - grupa 2) oraz 43 zdrowych pacjentów przyjętych w celu operacyjnego leczenia przepukliny pachwinowej, dawców rodzinnych części wątroby dla swoich zstępnych i zdrowych ochotników (kontrola pozytywna - grupa 3).

\section{Metoda}

Badania podjęte zostały w przekonaniu, że metoda cytometrii przepływowej umożliwia wykrycie frakcji endotelialnych komórek progenitorowych za pomocą znakowania przeciwciałami monoklonalnymi identyfikującymi antygeny: CD45, CD34, CD133 i CD309 (KDR) oraz określenie ich liczby we krwi obwodowej u chorych na raka wątrobowokomórkowego. Założono również, że liczba endotelialnych komórek progenitorowych we krwi obwodowej jest niska u ludzi zdrowych i u chorych na marskość wątroby, niezależnie od stopnia wydolności wątroby, lecz wzrasta znamiennie we krwi obwodowej u chorych na raka wątrobowokomórkowego. Badania przeprowadzono we współpracy z Pracownią Cytometrii Przepływowej Banku Komórek Krwiotwórczych i Krwi Pępowinowej Katedry i Kliniki Onkologii, Hematologii i Chorób Wewnętrznych Warszawskiego Uniwersytetu Medycznego, SP CSK WUM, Warszawa, ul. Banacha 1a. 
Od każdego z chorych pobrane zostały 2 mililitry (ml) żylnej krwi obwodowej do probówki z $\mathrm{K}_{3}$ EDTA. Pobranie nastąpiło w okresie po ustaleniu rozpoznania i/lub ukończeniu procesu kwalifikacji, lecz w okresie poprzedzającym bezpośrednio wykonanie operacji (resekcji albo przeszczepienia wątroby) lub bridging therapy u zakwalifikowanych do transplantacji, a także przed rozpoczęciem paliatywnego leczenia nieoperacyjnego u chorych leczonych zachowawczo.

Każda z próbek krwi przekazana została w czasie nieprzekraczającym 30 minut do Pracowni Cytometrii Przepływowej w Banku Komórek Krwiotwórczych i Krwi Pępowinowej Katedry i Kliniki Hematologii i Onkologii WUM. Analiza cytometryczna obejmowała identyfikację oraz ilościowe oznaczenie w populacji leukocytów CD45(+) (WBC), subpopulacji hematopoetycznych komórek macierzystych o fenotypie CD34(+)CD133(+)CD45(dim) (HSCs), a w niej frakcji endotelialnych komórek progenitorowych (EPCs), tj. komórek posiadających receptor powierzchniowy VEGFR-2, reagujących pozytywnie z monoklonalnym przeciwciałem anty-CD309 (KDR), tj. o fenotypie CD34(+) CD133(+)CD45(dim)CD309(+).

Oznaczeń dokonano według procedury wieloparametrycznej strategii bramkowania (the multiparametric cells gating strategy) służącej do oznaczania hematopoetycznych komórek macierzystych, rekomendowanej przez International Society of Hematology and Graft Engineering (ISHAGE). Założono, że częstość występowania endotelialnych komórek progenitorowych (EPCS) we krwi obwodowej osób zdrowych jest bardzo mała i nie przekracza 2500/ml.

W celu przygotowania próbki do oznaczenia właściwego do $100 \mu \mathrm{l}$ krwi dodawano $10 \mu \mathrm{l}$ przeciwciała anty-CD34 FITC (BD Biocsiences), $10 \mu$ l anty-CD133 PE (Miltenyi Biotec), $10 \mu$ l anty-CD45 PerCP (Biosciences) i $10 \mu$ l anty-CD309 APC (anty-VEGFR-2 APC-Miltenyi Biotec). Próbkę właściwą wykonywano w 7 powtórzeniach, tak aby zbadać komórki znajdujące się w $700 \mu \mathrm{l} \mathrm{krwi} \mathrm{obwodowej.} \mathrm{W} \mathrm{celu} \mathrm{przygotowania}$ próbki do oznaczenia kontrolnego do $100 \mu \mathrm{l}$ krwi dodawano $10 \mu \mathrm{l}$ przeciwciała anty-CD34 FITC (BD Biocsiences), $10 \mu \mathrm{l}$ anty-CD133 PE (Miltenyi Biotec), $10 \mu$ l anty-CD45 PerCP (Biosciences) i $10 \mu \mathrm{l}$ kontroli izotypowej z APC (Miltenyi Biotec). Próbkę kontrolną wykonywano w 3 powtórzeniach. Do przygotowanych w powyżej opisany sposób próbek oznaczenia właściwego i oznaczenia kontrolnego po 20 minutach inkubacji dodawany był odczynnik FACS Lysing Solution (BD Biosciences), powodujący lizę krwinek czerwonych. Następnie każda z próbek była ponownie inkubowana przez 10 minut, po czym płukana dwukrotnie w odczynniku CelIWash (BD Biosciences). Tak przygotowane próbki analizowane były niezwłocznie w cytometrze przepływowym FACS CANTO II (BD Biosciences). Dla próbki właściwej zbierano co najmniej 2 miliony komórek CD45(+) - leukocytów. Dla próbki kontrolnej zbierano co najmniej 1 milion komórek CD45(+) - leukocytów. Wyniki podawane były jako odse- tek endotelialnych komórek progenitorowych (\%EPCs) we frakcji hematopoetycznych komórek macierzystych (HSCs) i odsetek hematopoetycznych komórek macierzystych (\%HSCs) w populacji leukocytów (WBC).

Dane przedstawione zostały w postaci średniej oraz mediany z uwzględnieniem odchylenia standardowego. Zależności statystyczne pomiędzy odsetkiem endotelialnych komórek progenitorowych (EPCs) i hematopoetycznych komórek macierzystych (HSCs), cechami fizycznymi nowotworu określonymi na podstawie badań obrazowych (wielkością i liczbą ognisk guza), stopniem wydolności wątroby (poziom albumin, bilirubiny, transaminaz i fosfatazy zasadowej) oraz poziomem w surowicy krwi markera AFP - alfa-fetoproteiny oznaczone zostały dla każdej z grup chorych na raka wątrobowokomórkowego w odniesieniu do grup kontrolnych. U chorych, którzy przebyli leczenie operacyjne, w analizie uwzględniono dane zawarte w opisie operacji i wyniku badania histopatologicznego wyciętego preparatu.

Opracowanie danych i analiza statystyczna wyników przeprowadzona została w Zakładzie Informatyki Medycznej iTelemedycyny Warszawskiego Uniwersytetu Medycznego, SPCSKWUM, Warszawa, Banacha 1a.Zależności statystyczne określono za pomocą testu U Manna-Whitneya, poszerzonego o test ANOVA rang Kruskala-Wallisa oraz test korelacji rang Pearsona-Spearmana, uznając wartości poniżej $0,05(p<0,05)$ za znamienne statystycznie.

\section{Wyniki badań}

U wszystkich osób biorących udział w badaniu, tj. u chorych na HCC, u chorych na marskość wątroby i u osób z wątrobą zdrową w puli krwinek białych CD45(+) (WBC) stwierdzono obecność populacji hematopoetycznych komórek macierzystych o fenotypie CD34(+)CD133(+)CD45(dim) (hematopoietic stem cells - HSCs), a w niej - frakcji komórek progenitorowych, posiadających na powierzchni błony komórkowej receptor VEGFR-2 (vascular endothelial growth factor receptor 2), reagujący pozytywnie z przeciwciałem monoklonalnym anty-CD309. Komórki o tym fenotypie uznawane są powszechnie za endotelialne komórki progenitorowe (endothelial progenitor cells - EPCs).

Statystyki opisowe oznaczone dla subpopulacji hematopoetycznych komórek macierzystych w populacji leukocytów (\%HSCs/WBC) wynosiły Me =0,02 (SD +/- 0,01), $\mathrm{Me}=0,013(\mathrm{SD}+/-0,01)$, Me =0,03 (SD +/-0,01), a dla frakcji endotelialnych komórek progenitorowych w subpopulacji komórek macierzystych (\%EPCs/HSCs) wynosiły $\mathrm{Me}=2,83(\mathrm{SD}+/-3,78), \mathrm{Me}=2,81(\mathrm{SD}+/-1,71), \mathrm{Me}=1,36$ (SD +/- 1,94), odpowiednio dla chorych na raka, chorych na marskość wątroby i osób zdrowych. Różnice w odsetku hematopoetycznych komórek macierzystych w populacji leukocytów (\%HSCs/WBC) i w odsetku endotelialnych komórek progenitorowych w populacji hematopoetycznych 

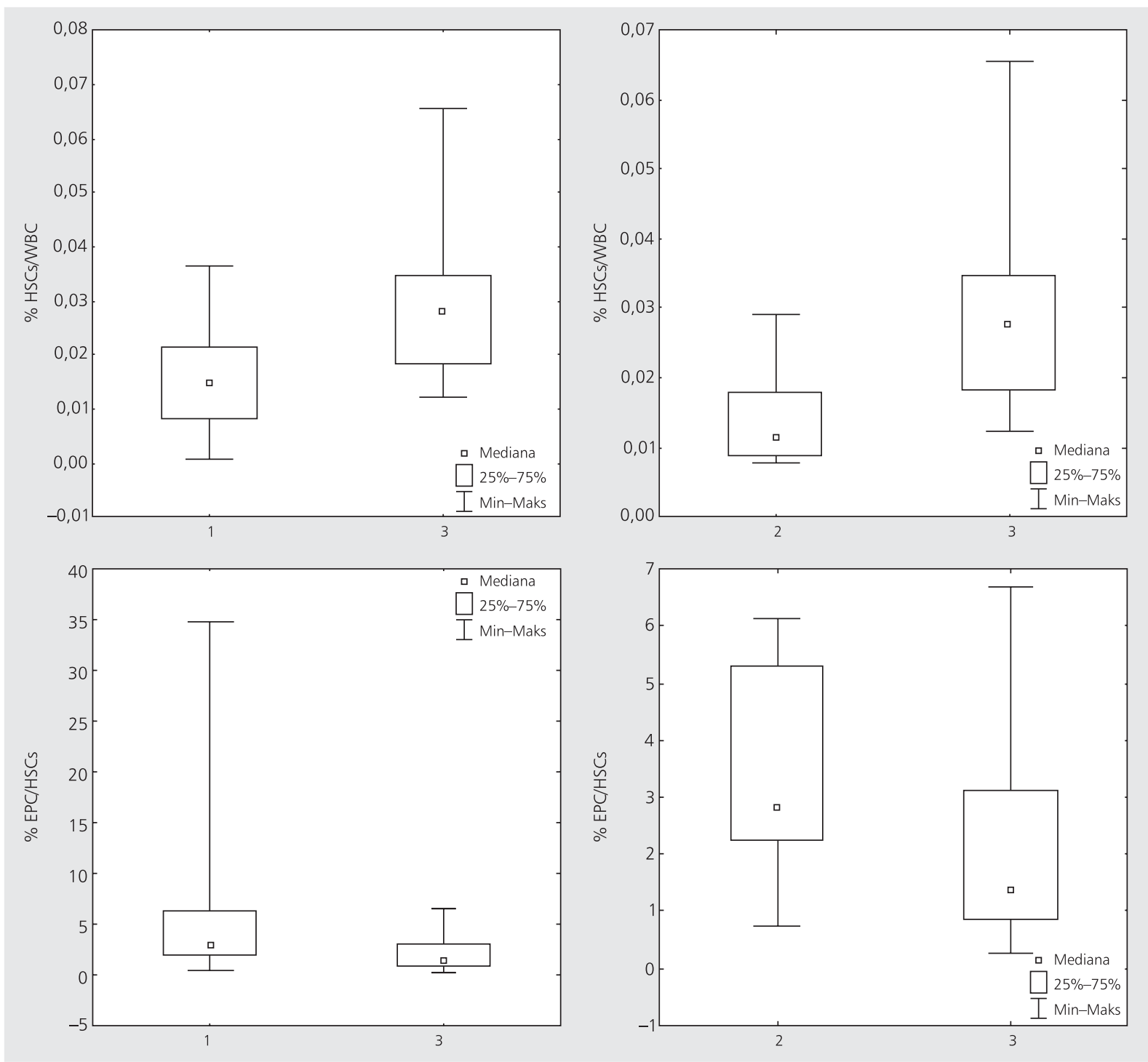

Rycina 1. Analiza statystyczna odsetka hematopoetycznych komórek macierzystych (\%HSCs/WBC) i endotelialnych komórek progenitorowych w subpopulacji hematopoetycznych komórek macierzystych (\%EPCs/HSCs) we krwi obwodowej w grupie chorych na HCC i w grupach kontrolnych: grupa 1 - chorzy na HCC; grupa 2 - chorzy z marskością, bez raka; grupa 3 - osoby z wątrobą zdrową. Wartości testu U Manna-Whitneya:

dla zmiennej (\%HSCs/WBC): Gr. 1 vs Gr. 3 - chisq $=-5,92 ; \mathrm{p}<0,0001$ Gr. 2 vs Gr. 3 - chisq $=-6,09 ; p<0,0001$ Gr. 1 vs Gr. 2 - (NS)

komórek macierzystych (\%EPCs/HSCs) pomiędzy chorymi na raka wątrobowokomórkowego (grupa 1) a osobami mającymi zdrową wątrobę (grupa 3) były znamienne statystycznie. Wartości testu U Manna-Whitneya wynosiły: dla zmiennej \%HSCs/WBC chisq $=-5,92, \mathrm{p}<0,0001$, a dla zmiennej \%EPCs/HSCs chisq = 3,85; $\mathrm{p}<0,0001$. Znamienne różnice zaistniały również pomiędzy chorymi z grup kontrolnych, tj. chorymi na marskość wątroby (grupa 2), a osobami z wątrobą zdrową (grupa 3). Wartości testu wynosiły: dla zmiennej \%HSCs/WBC chisq $=-6,09, \mathrm{p}<0,0001$, a dla zmiennej \%EPCs/HSCs chisq 2,47; $p<0,0001$. Nie stwierdzono natomiast znamiennych statystycznie różnic (NS) w odsetku hematopoetycznych komórek macierzystych
dla zmiennej (\%EPCs/HSCs): Gr. 1 vs Gr. 3 - chisq = 3,85; $\mathrm{p}<0,0001$ Gr. 2 vs Gr. 3 - chisq $=2,47 ; \mathrm{p}<0,0001$ Gr. 1 vs Gr. 2 - (NS)

w puli leukocytów (\%HSCs/WBC) i endotelialnych komórek progenitorowych w subpopulacji hematopoetycznych komórek macierzystych (\%EPCs/HSCs) pomiędzy chorymi na HCC (grupa 1) i chorymi na marskość wątroby, lecz bez HCC (grupa 2). Dane przedstawione zostały na rycinie 1.

Porównując średnie wartości odsetka frakcji hematopoetycznych komórek macierzystych (\% HSCs/WBC) i endotelialnych komórek progenitorowych (\% EPCs/HSCs) w grupie z HCC (grupa 1), stwierdzono istotne różnice pomiędzy chorymi, którzy z uwagi na stan wydolności wątroby i stopień zaawansowania raka zostali zakwalifikowanymi do radykalnego leczenia operacyjnego za pomocą resekcji lub transplantacji wątroby (grupa $1 \mathrm{~A}+1 \mathrm{~B}$ ) 


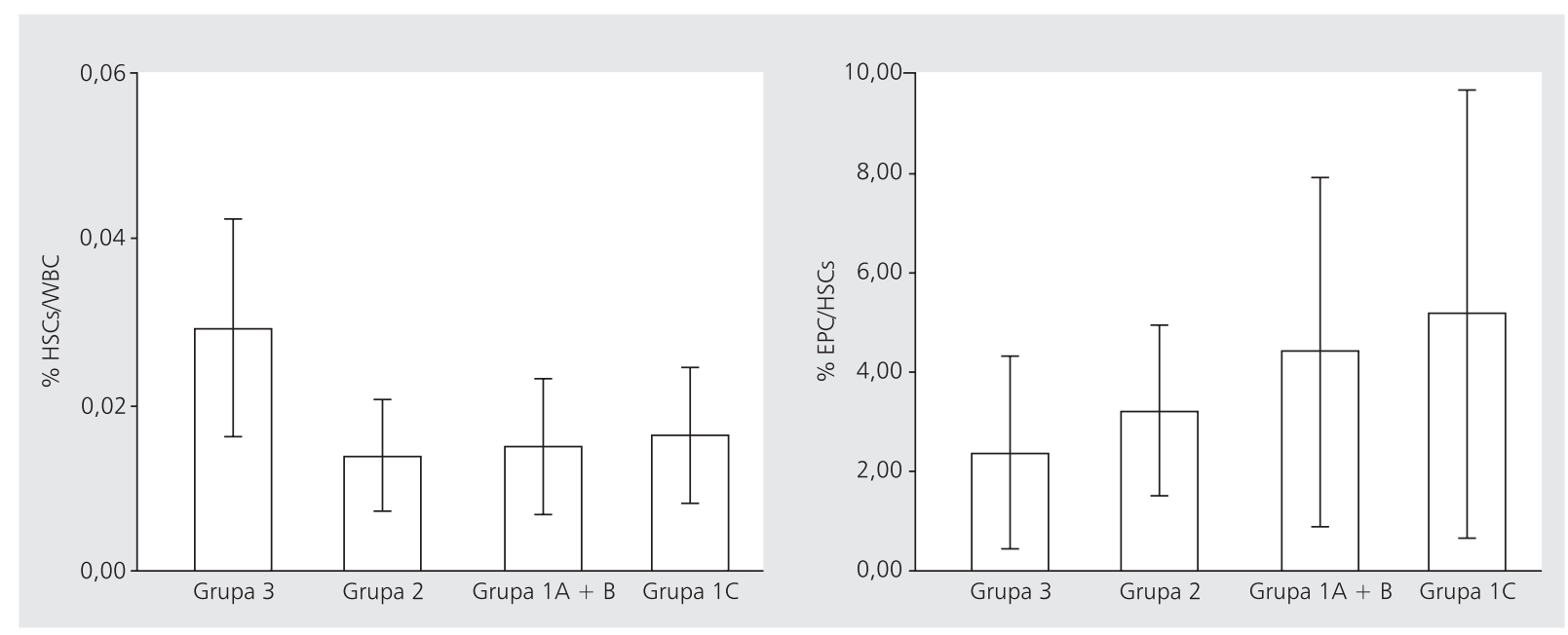

Rycina 2. Średnie wartości odsetka komórek progenitorowych (\%HSCs/WBC) i (\%EPCs/HSCs) we krwi obwodowej osób z wątrobą zdrową (grupa 3), chorych na marskość wątroby (grupa 2) i chorych na HCC; grupa 1A + B - chorzy kwalifikowani do resekcji i transplantacji wątroby; grupa 1-C — chorzy kwalifikowani do leczenia paliatywnego

a chorymi skierowanymi do leczenia paliatywnego (grupa 1-C). Odpowiednie wartości średnich wynosiły: dla grupy chorych zakwalifikowanych do resekcji i transplantacji wątroby (grupa 1A + 1B) \%HSCs/WBC = 0,015 (SD +/- 0,009) i dla $\%$ EPCS/HSCs $=4,41(S D+/-4,52)$, a dla grupy chorych zakwalifikowanych do leczenia paliatywnego (grupa 1-C) $\% H S C s / \mathrm{WBC}=0,016$ (SD +/-0,008) i \%EPCs/HSCs = 5,16 (SD $+/-4,51$ ). Dla porównania: w grupie osób zdrowych (grupa 3) $\% H S C s / W B C=0,029$ (SD +/-0,013), \%EPCs/HSCs: = 2,36 (SD $+/-1,93)$, a w grupie chorych na marskość wątroby (grupa 2) $\% H S C s / W B C=0,016$ (SD +/-0,008), \%EPCs/HSCs = 5,16 (SD $+/-4,51)$. Dane przedstawiono na rycinie 2 .

Analiza wyników uzyskanych w grupie chorych na raka wątrobowokomórkowego za pomocą testu korelacji rang Spearmana wykazała istotną zależność i korelację pomiędzy odsetkiem endotelialnych komórek progenitorowych w subpopulacji hematopoetycznych komórek macierzystych (\%EPC/HSCs) a odsetkiem hematopoetycznych komórek macierzystych w puli leukocytów (HSCs/WBC). Współczynnik korelacji w całej grupie chorych na HCC (grupa 1) wynosił $r=-0,58, p<0,0001$, w podgrupie 1-A $r=-0,55$; $\mathrm{p}<0,0001$, w podgrupie 1-B $r=-0,51 ; \mathrm{p}<0,0001$, w podgrupie 1-C $r=-0,71 ; p<0,0001$. Takich zależności i korelacji nie stwierdzono ani w grupie chorych na marskość wątroby (grupa 2), ani też w grupie osób z wątrobą zdrową (grupa 3). Dane przedstawiono na rycinie 3.

Badania endotelialnych komórek progenitorowych (EPCs) i hematopoetycznych komórek macierzystych (HSCs) w krążeniu obwodowym u chorych na raka wątrobowokomórkowego wskazują na istotne zależności pomiędzy wymienionymi subpopulacjami a niektórymi wartościami biochemicznymi i danymi klinicznymi, które stanowiły podstawę kwalifikacji chorych do odpowiedniego sposobu leczenia. Odsetek hematopoetycznych komórek macie-

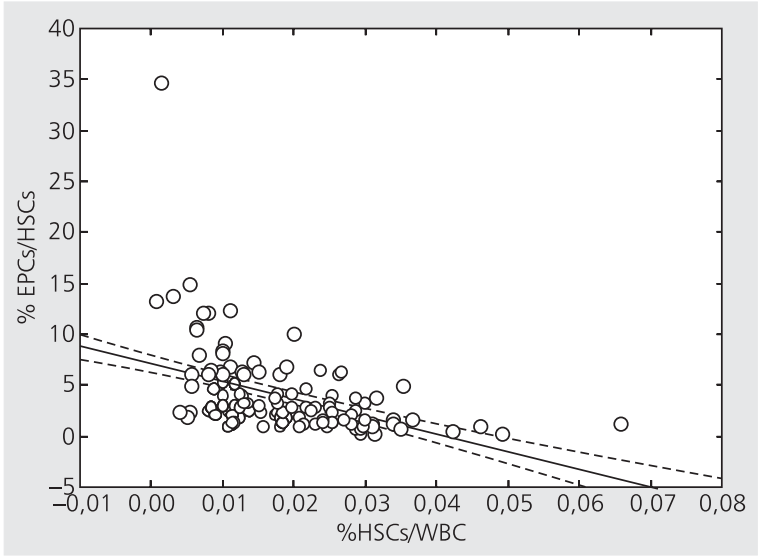

Rycina 3. Korelacja porządku rang Spearmana pomiędzy odsetkiem endotelialnych komórek progenitorowych w subpopulacji hematopoetycznych komórek macierzystych (\%EPCs/HSCs) i subpopulacji hematopoetycznych komórek macierzystych w puli leukocytów (\%HSCs/WBC) w grupie chorych na HCC (grupa 1); podgr. 1-A resekcja wątroby; podgr. 1-B transplantacja wątroby; podgr. 1-C leczenie paliatywne. Oznaczone współczynniki korelacji wynoszą: dla całej grupy $1: r=-0,58 ; p<0,0001$; dla podgr. 1-A: $r=-0,55$; $p<0,0001$; dla podgr. 1-B: $r=-0,51 ; p<0,0001$; dla podgr. 1-C: $r=-0,71 ; p<0,0001$

rzystych w puli leukocytów (\%HSCs/WBC) był znamiennie niższy, natomiast odsetek endotelialnych komórek progenitorowych w puli komórek macierzystych (\%EPCs/HSCs) — znamiennie wyższy u chorych na HCC w wątrobie marskiej niż u chorych z HCC w wątrobie zdrowej. Najwyższe odsetki hematopoetycznych komórek macierzystych (\%HSCs/WBC) we krwi chorych na HCC (grupa 1) obserwowano w przypadkach, w których guz rozwinął się w zdrowej wątrobie, pośrednie — gdy podłożem była marskość pozapalna HBV/HCV, a najniższe w przypadkach guzów, które powstały na tle marskości poalkoholowej. Odwrotnie 

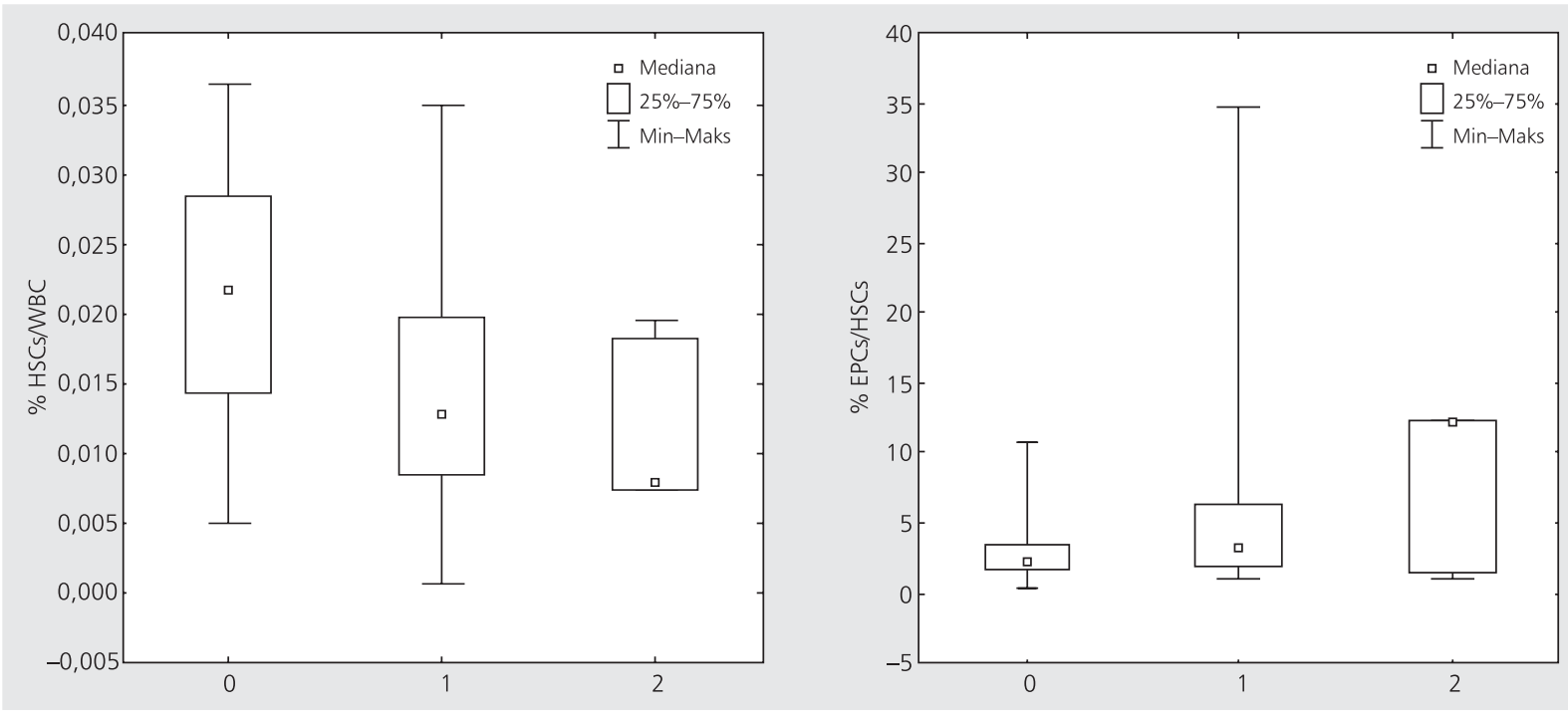

Rycina 4. Odsetek hematopoetycznych komórek macierzystych w puli leukocytów (\%HSCs/WBC) i endotelialnych komórek progenitorowych w subpopulacji hematopoetycznych komórek macierzystych (\%EPCs/HSCs) w grupie chorych na HCC (grupa 1) z marskością i bez marskości wątroby. Wartości testu Kruskala-Wallisa ANOVA rang dla zmiennej \%HSCs/WBC: chisq = 14,27; p < 0,0008; dla zmiennej (\%EPCs/HSCs): chisq = 10,97; p < 0,0004. 0 - chorzy na HCC ze zdrową wątrobą; 1 - chorzy na HCC z marskością pozapalną HBV, HCV; 2 - chorzy na HCC z marskością poalkoholową

przedstawiał się rozkład wartości odsetka endotelialnych komórek progenitorowych (\%EPCs/HSCs): najwyższe wartości obserwowano u chorych na marskość poalkoholową, pośrednie w marskości pozapalnej HBV/HCV, a najniższe - u osób z wątrobą zdrową. Różnice te były znamienne statystycznie; wartości testu Kruskala-Wallisa ANOVA rang dla zmiennej \%HSCs/WBC: chisq $=14,27 ; \mathrm{p}<0,0008$; dla zmiennej \%EPCs/HSCs: chisq $=10,97 ; p<0,0004$. Dane przedstawiono na rycinie 4.

Podwyższony poziom aktywności fosfatazy zasadowej (ALP) w surowicy krwi u chorych na HCC powyżej 120 U/I (norma 120 U/I ALP wg ustalenia Centralnego Laboratorium SP (SKWUM), a więc cech wewnątrzwątrobowej cholestazy, towarzyszył wzrostowi odsetka hematopoetycznych komórek macierzystych (\%HSCs/WBC) i endotelialnych komórek progenitorowych (\%EPCs/HSCs) we krwi obwodowej chorych na HCC (grupa 1). Test U Manna-Whitneya wykazał znamienną różnicę u chorych na HCC, u których poziom ALP był wyższy od $120 \mathrm{U} / \mathrm{l}$ w stosunku do chorych bez cech cholestazy (dla zmiennej \%HSCs/WBC, chisq = -2,28; $\mathrm{p}<0,02$ i dla zmiennej \%EPCs/HSCVs: chisq = 2,26; $<<0,02$ ). Dane przedstawiono na rycinie 5 .

Statystycznie znamienne różnice stwierdzono również pomiędzy chorymi na HCC z niskim i wysokim poziomem alfa-fetoproteiny (AFP) w surowicy krwi (norma wg ustalenia Centralnego Laboratorium SPCSK WUM wynosi $7 \mathrm{mi}-$ krogramów/litr). Odsetek hematopoetycznych komórek macierzystych (\%HSCs/WBC) i endotelialnych komórek progenitorowych (\%EPCs/HSCs) u osób z poziomem AFP > 7 mikrogramów/l we krwi obwodowej był statystycznie zna- miennie wyższy niż u chorych z poziomem AFP $<7$ mikrogramów/l (chisq = 2,15; $\mathrm{p}<0,03$ dla zmiennej \%HSCs/WBC i chisq $=-3,24 ; p<0,001$ dla zmiennej $\%$ EPCs/HScs). Dane przedstawiono na rycinie 6 .

Nie obserwowano natomiast statystycznie znamiennych różnic w odsetku subpopulacji hematopoetycznych komórek macierzystych (\%HSCs/WBC) i frakcji endotelialnych komórek progenitorowych (\%EPCs/HSCs) we krwi obwodowej chorych na HCC w zależności od wielkości, lokalizacji i liczby ognisk guza nowotworowego, w zależności od podwyższonych ponad normę wartości niektórych wskaźników funkcji komórki wątrobowej, jak aminotransferazy alaninowej (ALT) i asparaginowej (AST), INR, poziomu bilirubiny i frakcji albumin, a także dehydrogenazy mleczanowej (LDH), której podwyższone stężenie w surowicy krwi traktowane jest jako negatywny czynnik prognostyczny w niektórych nowotworach o dużej dynamice.

\section{Omówienie wyników i dyskusja}

W Klinice Chirurgii Ogólnej, Transplantacyjnej i Wątroby Uniwersytetu Medycznego w Warszawie wśród pacjentów chorych na nowotwory złośliwe każdego roku leczonych jest średnio 150 chorych na raka wątrobowokomórkowego. Niemal w 80\% przypadków są to chorzy na marskość wątroby i nadciśnienie wrotne, kierowani do Kliniki przez lekarzy podstawowej opieki zdrowotnej z podejrzeniem choroby nowotworowej, a także przesyłani do leczenia w ośrodku referencyjnym przez oddziały specjalistyczne, także oddziały onkologii, z postawionym już rozpoznaniem raka wątrobowokomórkowego. Spośród 677 chorych na HCC leczonych 


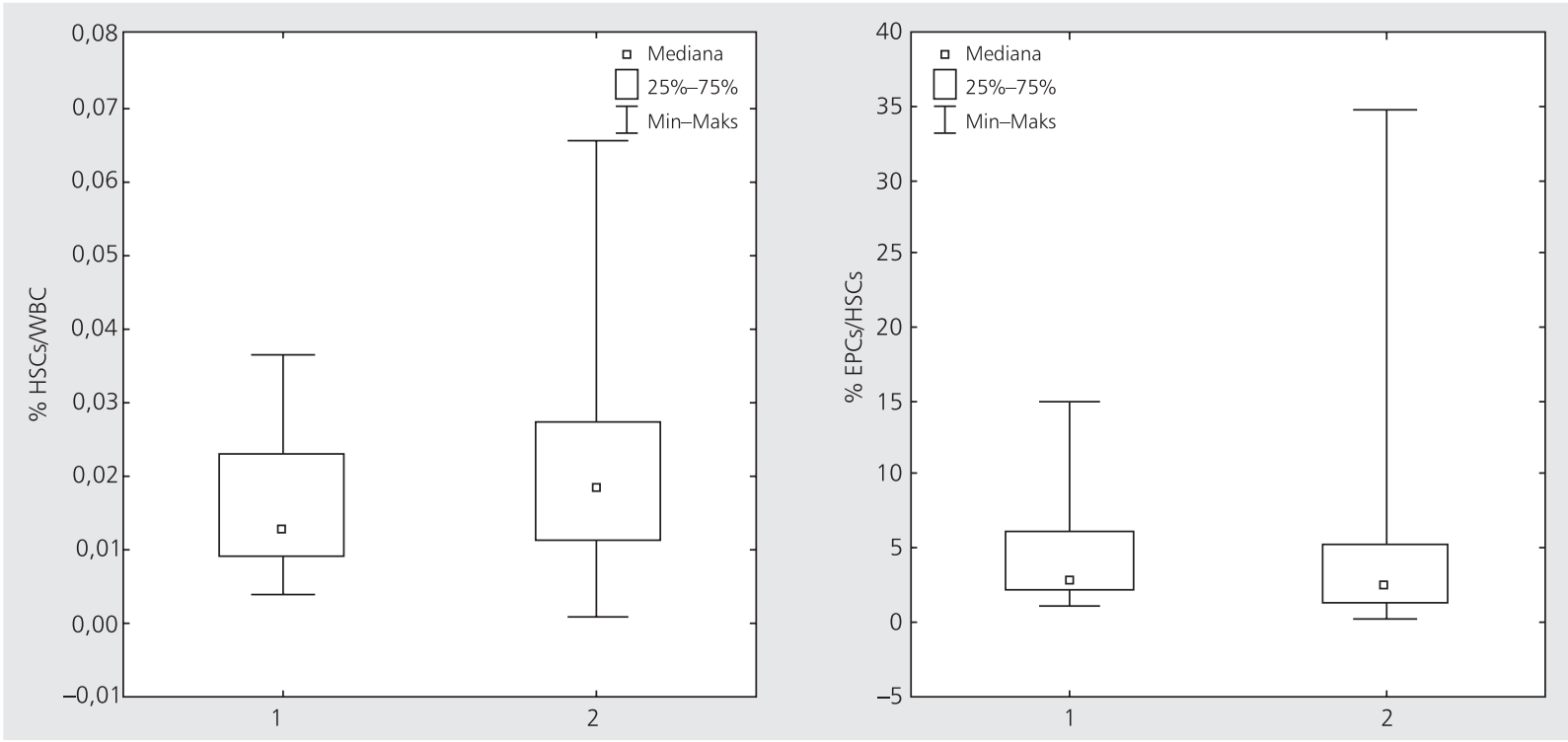

Rycina 5. Odsetek hematopoetycznych komórek macierzystych w puli leukocytów (\%HSCs/WBC) i endotelialnych komórek progenitorowych w subpopulacji hematopoetycznych komórek macierzystych (\%EPCs/HSCs) u chorych na HCC z prawidłowym (1) i podwyższonym (2) poziomem fosfatazy zasadowej (ALP)

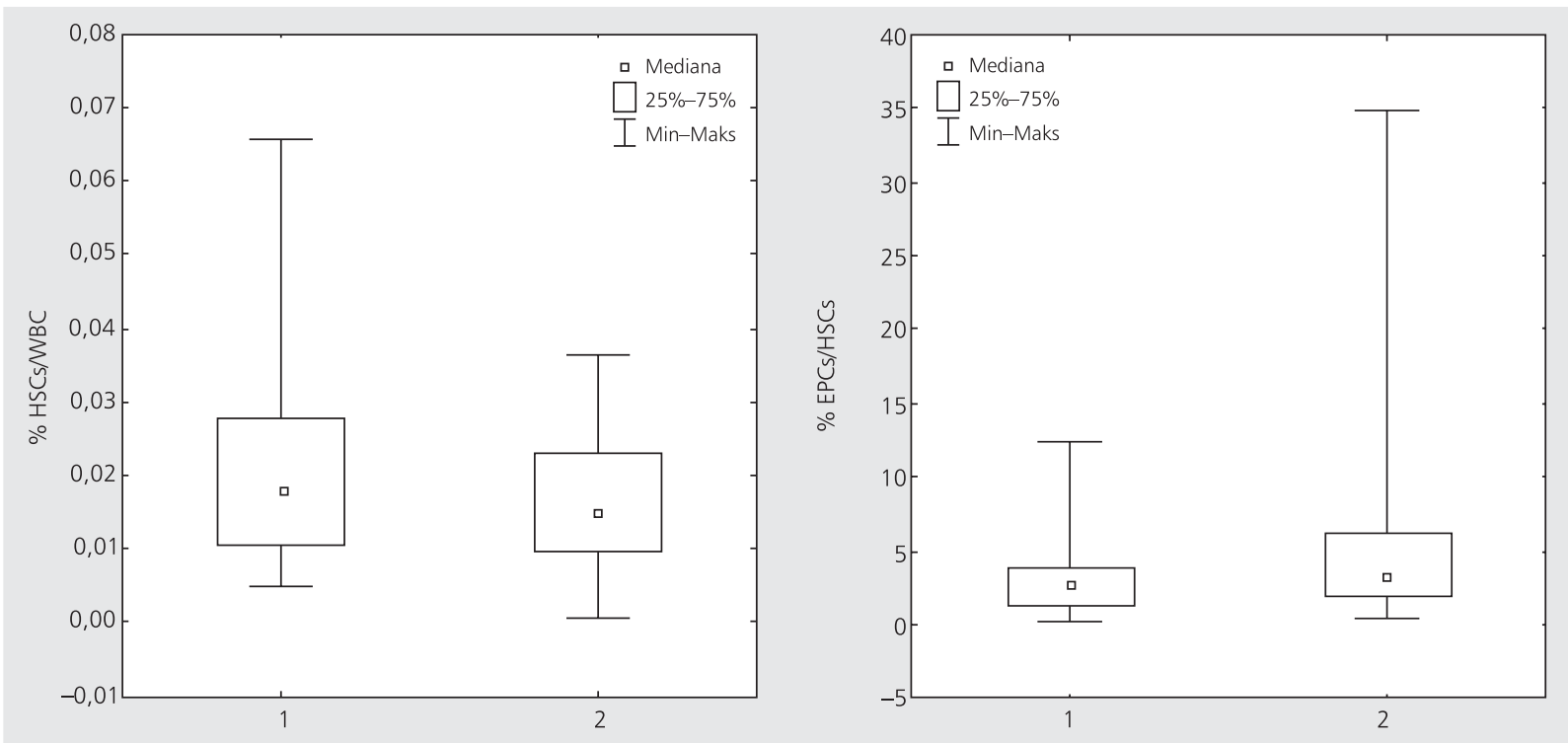

Rycina 6. Odsetek hematopoetycznych komórek macierzystych w puli leukocytów (\%HSCs/WBC) i endotelialnych komórek progenitorowych w subpopulacji hematopoetycznych komórek macierzystych (\%EPCs/HSCs) u chorych na HCC z prawidłowym (1) i podwyższonym (2) poziomem alfa-fetoproteiny (AFP)

w latach 2009-2012 515 chorych, tj. 76,1\% po przeprowadzeniu oceny stanu wydolności wątroby i stopnia zaawansowania choroby nowotworowej (klasyfikacja Childa-Pugha, MELD, BCLC, kryteria mediolańskie) skierowanych zostało do paliatywnej farmakoterapii, chemioembolizacji oraz leczenia objawowego. W naszych warunkach radykalne leczenie chirurgiczne chorych na raka wątrobowokomórkowego za pomocą resekcji lub transplantacji wątroby okazuje się zatem możliwe u mniej niż 25\% chorych. W okresie 2009-2012 na ogólną liczbę 585 przeprowadzonych w Klinice przeszczepień wątroby w 84 przypadkach transplantację wykonano u chorych na HCC. Okres przeżycia po przeszczepieniu nie odbiegał znamiennie od okresu przeżycia chorych, u których przeszczepu dokonano ze wskazań nienowotworowych, i wynosił po roku $83,7 \%$, po 2 latach $82,0 \%$, po 4 latach $75,7 \%$ dla HCC oraz po roku $86,5 \%$, po 2 latach $84,7 \%$, po 4 latach $82,1 \%$ dla wskazań nienowotworowych, $p<0,573$. Kandydatami do wykonania resek- 
cji lub przeszczepienia wątroby byli chorzy z grupy A i B według klasyfikacji Childa-Pugha, którzy spełniali kryteria standardowej oceny klinicznej (BCLC, kryteria mediolańskie), przy czym u 12 chorych odstąpiono od resekcji dopiero po wykonaniu laparotomii, a u 6 innych po wykonaniu laparoskopii zwiadowczej odstąpiono od dalszej kwalifikacji do przeszczepienia wątroby. Dane te obrazują dylematy w podejmowaniu decyzji o leczeniu operacyjnym oraz trudności związane z kwalifikacją chorych i uzasadniają podjęcie badań przyczyniających się do poszerzenia możliwości i skali oceny klinicznej.

Wyniki badań podstawowych i badań klinicznych potwierdzają rolę, jaką w dynamicznym rozwoju raka wątrobowokomórkowego odgrywa angiogeneza. Czynnikiem wyzwalającym angiogenezę jest postępujące w miarę wzrostu guza niedotlenienie tkanki i aktywność cytokin nowotworowych [1, 11, 22, 23]. Szczególną rolę w tym procesie przypisuje się czynnikowi wzrostu śródbłonka naczyniowego (VEGF), którego działanie jest katalizatorem przemian i uwalniania ze szpiku kostnego komórek progenitorowych, w wyniku czego ich liczebność w krążeniu obwodowym wzrasta. Mechanizm ten zaobserwowano u wielu chorych na nowotwory złośliwe, w tym także u chorych na raka wątrobowokomórkowego. Oznaczenia ilościowe krążących komórek progenitorowych (circulating progenitor cells - cPCs) umożliwiły badania wykonywane metodą cytometrii przepływowej, wykorzystującą przeciwciała monoklonalne połączone z fluorochromami [21, 24-30].

Nieporozumienia i kontrowersje, jakie narosły wokół wyników niektórych badań, wynikały zazwyczaj z niejednoznacznej definicji określającej fenotyp komórek uczestniczących w nowotworzeniu naczyń krwionośnych. Stosowano całą gamę różnych przeciwciał, zakładając, że endotelialne komórki progenitorowe są populacją blastów i wywodzą się z pierwotnych miejsc hematopoezy, a w życiu pozapłodowym — ze szpiku kostnego. W rzeczywistości znajdują się one w populacji leukocytów, tj. krwinek o fenotypie charakteryzującym się dodatnią reakcją z monoklonalnym przeciwciałem powierzchniowym anty-CD45 i stanowią heterogenną grupę blastów, których charakterystyka zmienia się zarówno z wiekiem, jak i w zależności od ich przeznaczenia. Jedną z subpopulacji są hematopoetyczne komórki macierzyste (HSC), blasty mogące różnicować się w kierunku hematopoetycznym i endotelialnym, tworzą c w tym drugim przypadku frakcję endotelialnych komórek progenitorowych [31-35]. W pracy przedmiotem oceny była obecność w krążeniu obwodowym u chorych na HCC obydwu wspomnianych powyżej populacji komórek. Subpopulacja macierzystych komórek hematopoetycznych (HSCs) zasługuje na uwagę jako pierwotna linia i potencjalne źródło komórek endotelium naczyniowego. Ich macierzysty charakter potwierdza obecność na powierzchni błony komórkowej glikoproteiny CD34, molekuły adhezyjnej i aktywatora re- akcji pomiędzy nabłonkiem i prekursorami hematopoezy oraz obecność antygenu CD133, charakterystycznego m.in. dla blastów różnicujących się do wielorakich fenotypowo komórek macierzystych, także endotelialnych. Natomiast frakcję endotelialnych komórek progenitorowych spośród innych hematopoetycznych blastów wyróżnia obecność na błonie komórkowej białka receptorowego VEGFR-2 (vascular endothelial growth factor receptor-2), reagującego na sygnały VEGF, mediatora proliferacji i migracji komórkowej, formowania tubuli naczyniowych, obecnego na błonach komórkowych najbardziej pierwotnych w formie i zróżnicowaniu komórkach macierzystych [27, 32, 33, 35-40]. Pozytywna reakcja z monoklonalnymi przeciwciałami anty-CD45, anty-CD34, anty-CD133 i anty-CD309 jest charakterystyczną i zarazem najbardziej restrykcyjną formą określenia fenotypu hematopoetycznych i endotelialnych komórek progenitorowych. Wyklucza zarazem błędne rozpoznanie i oznaczenie innych frakcji komórkowych, np. dojrzałych komórek endotelialnych, które są CD45(-). Kluczowym momentem w badaniu cytometrycznym populacji rzadkich, takich jak hematopoetyczne i endotelialne komórki progenitorowe, jest także prawidłowo użyta kontrola izotypowa. Przyjęta w projekcie procedura oznaczeń hematopoetycznych komórek progenitorowych przebiegała zgodnie z wieloparametryczną strategią bramkowania (the multi parametric cells gating strategy), rekomendowaną przez International Society of Hematology and Graft Engineering (ISHAGE), natomiast wyodrębnienie subpopulacji CD309(+) odbywało się zgodnie z zasadą kontroli izotopowej typu FMO (fluorescence-minus-one) próbki kontrolnej, w której użyte są wszystkie przeciwciała za wyjątkiem jednego — badanego FMO controls are samples labeled with all antibodies of the multicolor test sample except one [41, 42]. W naszym eksperymencie było to przeciwciało anty-CD309.

Analiza uzyskanych wyników pozwala na wskazanie kilku istotnych prawidłowości. Odsetek hematopoetycznych komórek progenitorowych w populacji leukocytów (\%HSCs/WBC) był znamiennie niższy u chorych na HCC i u chorych na marskość wątroby, bez stwierdzonego raka, w porównaniu z osobami, które miały wątrobę zdrową. Chorych na raka wątrobowokomórkowego i chorych na marskość wątroby, bez stwierdzonego raka, wyróżniał natomiast wysoki odsetek endotelialnych komórek progenitorowych w subpopulacji hematopoetycznych komórek macierzystych (\%EPCs/HSCs). Niewielkie różnice obserwowane pomiędzy chorymi z HCC i chorymi na marskość bez HCC nie były istotne statystycznie. Opisane zmiany związane są prawdopodobnie z przebiegiem procesu angiogenezy w warunkach fizjologii i patologii. W warunkach fizjologii proces angiogenezy związany jest z proliferacją pericytów, tzw. mural cells oraz komórek endotelialnych, zwłaszcza tych znajdujących się w zatokach wątroby (liver sinusoidal endothelium cells - LSECs). W marskości wątroby proces 
regeneracji miąższu i proces angiogenezy ulega nasileniu i spaczeniu. Zmiany charakteryzuje nasilone włóknienie, modelowanie zatok wątroby i proliferacja komórek. W nowotworzeniu naczyń udział biorą nie tylko komórki „,miejscowe” (LSECs) czy komórki gwiaździste (stellate cells - SCs), lecz także komórki mobilizowane na drodze szlaków sygnałowych z innych źródeł, np. szpiku kostnego na drodze hematopoezy. Rozwój raka wątrobowokomórkowego, zwłaszcza gdy powstaje w marskiej wątrobie, nasila proliferację. Aktywność komórek progenitorowych we krwi obwodowej wzrasta pod wpływem cytokin nowotworowych, takich jak VEGF.W rezultacie w krążeniu obwodowym chorych na marskość wątroby i chorych na raka wątrobowokomórkowego wzrasta odsetek endotelialnych komórek progenitorowych w subpopulacji hematopoetycznych komórek macierzystych (\%EPCS/HScs), lecz jednocześnie maleje ogólnoustrojowy „potencjał angiogenezy”, wyrażony odsetkiem macierzystych komórek hematopoetycznych w populacji białych krwinek (\%HSCs/WBC). Przedstawione wyniki znajdują potwierdzenie w wielu innych obserwacjach, a zarazem dostarczają kolejnego dowodu wskazującego na marskość wątroby jako na stan przedrakowy [10, 22, 43-48].

Znamienna statystycznie korelacja pomiędzy malejącym odsetkiem subpopulacji progenitorowych komórek hematopoetycznych (\%HSCs/WBC) i wzrastającym odsetkiem frakcji komórek endotelialnych (\%EPCs/WBC) u chorych z HCC (grupa 1) wskazuje, że rozwój nowotworu nie wywołuje, lecz nasila proces angiogenezy, naturalny w przebiegu regeneracji w wątrobie zdrowej, a patologiczny w wątrobie marskiej. U osób mających wątrobę zdrową (grupa 3) i u chorych na marskość wątroby, bez stwierdzonego raka (grupa 2) tej korelacji nie stwierdzono. Wydaje się więc, że jest to immanentna i wyróżniająca cecha powstającego w wątrobie raka, a wpływ nowotworu na procesy regeneracji, proliferacji i angiogenezy wydaje się tym większy, im bardziej uszkodzona jest wątroba, w której rak powstał. Czy zatem stopień endotelialnych komórek progenitorowych w krążeniu obwodowym chorych na HCC odzwierciedla stopień zaawansowania raka? Problem budzi kontrowersje i jest przedmiotem intensywnych badań prowadzonych w wielu ośrodkach na całym świecie. Wyniki wielu badań sugerują, że mobilizacja i osiedlanie się endotelialnych komórek progenitorowych w rejonie tworzącego się raka są specyficzną właściwością tzw. nowotworów litych, jak np. HCC. Właściwość ta wyraża się w obrazie klinicznym choroby poprzez zwiększenie krążących we krwi obwodowej komórek progenitorowych raka (CSCs), także komórek endotelialnych (EPCs). Wykrycie i oznaczenie ich populacji umożliwia rozpoznanie, ocenę stopnia zaawansowania choroby i rokowania, a także monitorowanie przebiegu i wyników leczenia [7, 14, 24, 43, $47,49,50,52]$. Wyniki wielu innych badań sugestii tych nie potwierdzają [8, 20, 26, 40, 45, 51]. Badania własne wskazują, że w porównaniu do osób z wątrobą zdrową odsetek hema- topoetycznych i endotelialnych komórek progenitorowych drastycznie zmniejsza się u chorych na marskość wątroby, lecz u chorych na HCC sukcesywnie wzrasta w zależności od stanu chorego i stopnia zaawansowania raka (vide wyniki i rycina 2). Wartości obserwowane w grupie HCC (grupa 1) były najniższe u chorych, którzy na postawie klasyfikacji Childa-Pugha i kryteriów mediolańskich kwalifikowali się do wykonania resekcji wątroby, a wartości najwyższe obserwowano u chorych, u których resekcja lub transplantacja wątroby zostały wykluczone z powodu zaawansowania choroby nowotworowej i niewielkiej rezerwy czynnościowej, lub wręcz niewydolności wątroby. Podobne wyniki przedstawione zostały w piśmiennictwie przez Chih-Hung Chena i współpracowników z Chang Gung University na Tajwanie, którzy obniżenie aktywności EPCs u chorych na marskość wątroby uznali za „uderzające”. Jako hipotezę tłumaczącą ten fenomen sugerują, że zmiany, jakie zachodzą w procesie marskości wątroby, są w istocie przewlekłym i postępującym odczynem zapalnym. Proces ten stymuluje lokalne czynniki angiogenezy, komórki gwiaździste (SCs) i komórki endotelium zatok wątrobowych (LSECs), co w efekcie hamuje mobilizację endotelialnych komórek progenitorowych ze szpiku kostnego. Rozwój raka, zwłaszcza w wątrobie marskiej, zmienia proporcje w przebiegu angiogenezy, a intensywna mobilizacja EPCs ze źródeł pozawątrobowych przez cytokiny raka zwiększa odsetek komórek progenitorowych we krwi obwodowej proporcjonalnie do stopnia zaawansowania i aktywności nowotworu. Autorzy wykazali także korelację pomiędzy zmniejszającą się aktywnością komórek EPCs i pogarszającą się w ocenie klinicznej funkcją wątroby, od Childa-Pugha A do Childa-Pugha C, oraz znamiennie wyższą i wzrastającą sukcesywnie wraz ze stopniem zaawansowania choroby nowotworowej aktywność komórek EPCs [47]. Tym samym potwierdzili tezę o wzajemnej i pozytywnej relacji pomiędzy aktywnością komórek progenitorowych i stanem zaawansowania choroby nowotworowej. W swej opinii przyłączają się do poglądów takich badaczy jak De-cai Yu, Carr, Gadelhak i zapewne wielu innych [7, 14, 24, 30, 46, 47, 49, 52].

Do rozwoju HCC dochodzi przede wszystkim u chorych na marskość wątroby, która w 80-90\% przypadków wiąże się z zakażeniami HBV lub HCV oraz ich współwystępowaniem. U chorych na marskość wątroby HCC jest najczęstszą przyczyną zgonu. W krajach Azji i Afryki zachorowania na HCC wiążą się przede wszystkim z zakażeniem HBV, natomiast w Europie, także w Polsce i w Stanach Zjednoczonych oraz Japonii - częściej zależą od zakażenia HCV. Zachorowalność na HCC u chorych z marskością poalkoholową wątroby, która według nielicznych opracowań przekracza 2.5\%, w zbiorczych statystykach jest najczęściej pomijana [4, 5, 7, 48]. Spośród 134 chorych na HCC, którzy w okresie 2009-2012 leczeni byli w Klinice i uczestniczyli w badaniu komórek progenitorowych we krwi obwodowej, tylko u 31 chorych rak rozwinął się w wątrobie zdrowej; u 103, tj. 74\% cho- 
rych rak rozwinął się na podłożu marskości wątroby, w tym u 74 spowodowanej zakażeniem HBV/HCV, a u 29 — nadużywaniem alkoholu. Wyniki oceny komórek progenitorowych w krążeniu obwodowym u wymienionych chorych przedstawiają się interesująco; odsetek macierzystych komórek hematopoetycznych (\%HSCs/WBC) był najwyższy u chorych na HCC w wątrobie zdrowej, a najniższy u chorych na HCC i poalkoholową marskość wątroby. Odwrotnie — odsetek progenitorowych komórek endotelialnych (\%EPCs/HSCss) był najwyższy u chorych na HCC i na marskość poalkoholową, a najniższy u chorych na HCC w zdrowej wątrobie. Pośrednie wartości odsetka obu subpopulacji komórkowych obserwowano u chorych na marskość pozapalną HBV/HCV. Jest to kolejny argument popierający tezę, że rak nie tworzy nowych patomechanizmów, lecz wykorzystuje i wzmacnia mechanizmy właściwe dla homeostazy środowiska, w którym się rozwija. Paradoksalnie stanem bardziej sprzyjającym rozwojowi raka wątrobowokomórkowego wydaje się być marskość poalkoholowa wątroby, a nie marskość pozapalna HBV/HCV, jak sądzi się powszechnie.

Istotną częścią badania było odniesienie zmian odsetka krążących komórek progenitorowych do stanu klinicznego chorych. Każdy z biorących udział w badaniu poddany został szczegółowej ocenie, na podstawie której zakwalifikowany został do odpowiedniej grupy leczenia. Standardowo stosowaną oceną była klasyfikacja Childa-Pugha, MELD, BCLC i tzw. kryteria mediolańskie. Klasyfikacje te obejmują ocenę szeregu parametrów biochemicznych, objawów klinicznych i cech fizycznych rozwijającego się nowotworu. Badanie wykazało znamienne statystycznie zależności pomiędzy progenitorowymi komórkami HSCs i EPCs a podwyższonym w surowicy krwi chorych na HCC stężeniem fosfatazy zasadowej (ALP) ponad $120 \mathrm{U} / \mathrm{l}$ i alfa-fetoproteiny (AFP) ponad 7 mikrogramów/l. Podwyższone stężenie fosfatazy zasadowej, wykrywane w nowotworach wątroby, jest wyrazem cholestazy wewnątrzwątrobowej lub wzmożonej biosyntezy enzymu przez komórki nowotworowe w tzw. zespole paraneoplastycznym. Cholestaza w przebiegu HCC może być wywołana przez ucisk rozrastającego się guza na drogi żółciowe lub może być spowodowana niewydolnością komórki wątrobowej i jest jednym z objawów zespołu wątrobowo-nerkowego w marskości wątroby, zwłaszcza w przebiegu zakażenia wirusem hepatotropowym. Natomiast alfa-fetoproteina jest glikoproteiną wykorzystywaną szeroko w diagnostyce pierwotnego raka wątroby. Stanowi także podstawę programów badań przesiewowych, do których kwalifikowani są chorzy z grup wysokiego ryzyka. W wielu z nich wykazano, że odsetek trzyletniego przeżycia pacjentów leczonych chirurgicznie z powodu HCC z podwyższonym stężeniem AFP w surowicy jest znamiennie statystycznie niższy w porównaniu z chorymi, u których stężenie alfa-fetoproteiny było prawidłowe [4-6, 26, 43]. Wykazane w badaniu podwyższenie odsetka komórek pro- genitorowych krążących we krwi obwodowej u chorych na HCC z objawami cholestazy i podwyższonym stężeniem AFP w surowicy krwi sugeruje zatem, że oznaczenie komórek HSCs i EPCs może być pomocne w klinicznej ocenie rokowania u chorych na HCC i wyborze sposobu leczenia.

Przedstawione w pracy wyniki wpisują się w nurt doświadczeń potwierdzających potencjalnie użyteczną rolę komórek progenitorowych jako biomarkera w ocenie chorych na marskość wątroby i HCC. Wyniki tych doświadczeń są bardzo obiecujące, dotyczą one jednak głównie badań o charakterze podstawowym. Do określenia rzeczywistej wartości oznaczeń krążących EPCs u chorych na raka wątrobowokomórkowego brakuje obserwacji klinicznych i badań wieloośrodkowych na dużej populacji chorych. Sytuacja przypomina tę sprzed wielu lat, związaną z wprowadzeniem do powszechnej świadomości klinicznej i wykorzystania w praktyce alfa-fetoproteiny oraz innych używanych powszechnie markerów nowotworowych. Zważywszy na lawinowo postępujący rozwój badań i wielokierunkowy zakres prac nad komórkami macierzystymi, zapewne także i ten biomarker doczeka się wkrótce pełnej i krytycznej weryfikacji klinicznej.

\section{Wnioski}

Rozwój raka wątrobowokomórkowego wywołuje w krążeniu obwodowym chorych na marskość wątroby i HCC wzrost odsetka endotelialnych komórek progenitorowych (EPCS). Jednocześnie maleje ogólnoustrojowy „potencjał angiogenezy", wyrażony odsetkiem macierzystych komórek hematopoetycznych w populacji białych krwinek (\%HSCs/WBC). Nieistotne statystycznie różnice pomiędzy chorymi na raka i marskość wątroby potwierdzają tezę o przedrakowym charakterze marskości.

Znamienna statystycznie korelacja pomiędzy malejącym odsetkiem subpopulacji progenitorowych komórek hematopoetycznych (\%HSCs/WBC) i wzrastającym odsetkiem frakcji komórek endotelialnych (\%EPCs/HSCs) u chorych na HCC wskazuje, że rozwój nowotworu nie wywołuje, lecz nasila proces angiogenezy, naturalny w przebiegu regeneracji w wątrobie zdrowej, a patologiczny w wątrobie marskiej. Badania potwierdzają tezę o wzajemnej i pozytywnej relacji pomiędzy aktywnością komórek progenitorowych i stanem zaawansowania choroby nowotworowej. Tym samym oznaczenie komórek HSCs i EPCs we krwi obwodowej chorych na HCC może być pomocne w ocenie rokowania i w podjęciu decyzji o sposobie leczenia.

\section{Prof. dr hab. med. Włodzimierz Otto}

Katedra i Klinika Chirurgii Ogólnej, Transplantacyjnej i Wątroby, SP CSK WUM, ul. Banacha 1a, 02-097 Warszawa

Tel: +48 22599 2546, mob: +48602671176

e-mail:wotto@wum.edu.pl

Otrzymano: 12 czerwca $2013 \mathrm{r}$.

Przyjęto do druku: 18 lipca $2013 \mathrm{r}$. 


\section{Piśmiennictwo}

1. Hanahan D, Weinberg RA. The hallmarks of cancer. Cell 2000; 100:57-70.

2. Luo J, Solimini NL, Elledge SJ. Principles of cancer therapy: oncogene and non-oncogene addiction. Cell 2009; 136: 823-837.

3. Tanaka S, Arii S. Current status of molecularly targeted therapy for hepatocellular carcinoma: basic science. Int J Clin Oncol 2010; 15: 235-241.

4. Krzakowski M, Zieniewicz K, Habior A i wsp. Hepatocellular carcinom — diagnosis and treatment. Onkologia w Praktyce Klinicznej 2009; 4 125-140.

5. But DY, Lai CL, Yuen MF. Natural history of hepatitis-related hepatocellular carcinoma. World J Gastroenterol 2008; 14: 1652-1656.

6. Wójtowicz-Chomicz K, Cichoż-Lach H, Lis E i wsp. Ocena stężenia alfa-fetoproteiny u pacjentów z przewlekłymi schorzeniami wątroby. Pol Merk Lek 2012; 32: 374-377.

7. Carr BI. Hepatocellular carcinoma: current management and future trends. Gastroenterology 2004; 127: 218-224.

8. Jensen HM, Chen I, DeVault MR i wsp. Angiogenesis induced by "normal" human brest tissue: A probable marker for precancer. Science 1982; 218: 293-295.

9. Folkman J. What is the evidence that tumors are angiogenesis dependent. J Nat Cancer Inst 1990; 82: 4-6.

10. Kroemer G, Pouyssegur J.Tumor cell metabolism: cancer's Achilles' heel. Cancer Cell 2008; 13: 472-482.

11. Imanishi T, Tsujioka H, Akasaka T. Endothelial progenitor cells dysfuncyion and senescence: contribution to oxidative stress. Curr Cardiol Rev 2008; 4: 275-286.

12. Zampetaki A, Kirton JP, Qingbo Xu. Vascular repair by endothelial progenitor cells. Cardiovascular Research 2008 78, 413-421.

13. Kaplan RN, Riba RD, Zacharoulis S i wsp. VEGFR1-positive haematopoietic bone marrow progenitors initiate the premetastatic niche. Nature 2005: 438: 820-827.

14. De-cai Yu, Chen J, Sun Xi-tai i wsp. Mechanisms of endothelial progenitor cell recruitment into neo-vessels in adjacent non-tumor tissues in hepatocellular carcinoma. BMC Cancer 2010; 10: 435-445.

15. Peters BA, Diaz LA, Polyak Ki wsp. Contribution of bone marrow-derived endothelial cells to human tumor vasculature. Nat Med 2005: 11: 261-262.

16. Aicher A, Rentsch M, Sasaki KI i wsp. Non bone marrow-derived circulating progenitor cells contribute to postnatal neovascularization following tissue ischemia. Circ Res 2007; 100: 581-589.

17. Schatteman GC, Dunnwald M, Jiao C. Biology of bone marrow-derived endothelial cell precursors. Am J Physiol Heart Circ Physiol 2007; 292: 1-18.

18. Deli G, Jin $\mathrm{CH}$, Mu R. Immunohistochemical assessment of angiogenesis in hepatocellular carcinoma and surrounding cirrhotic liver tissues. World J Gastroenterol 2005; 11: 960-963.

19. Jin H, Aiyer A, Su Ji wsp. A homing mechanism for bone marrow-derived progenitor cell recruitment to the neovasculature. J Clin Invest 2006, 116: 652-662.

20. Beaudry P, Force J, Naumov GN i wsp. Differential effects of vascular endothelial growth factor receptor-2 inhibitor ZD6474 on circulating endothelial progenitors and mature circulating endothelial cells. Implications for use as surrogate marker of antiangiogenic activity. Clin Cancer Res 2005: 11: 3514-3522.

21. Kuroi K, Toi M. Circulating angiogenesis regulators in cancer patients. Int J Biol Markers 2001; 16: 5-26.

22. De Palma M, Venneri MA, Roca C i wsp. Targeting exogenous genes to tumor angiogenesis by transplantation of genetically modified hematopoietic stem cells. Nat Med 2003; 9: 789-795.

23. Huang $\mathrm{PH}, \mathrm{Chen} \mathrm{YH}$, Wang $\mathrm{CH}$ i wsp. Matrix metalloproteinase-9 is essential for ischemia-induced neovascularization by modulating bone marrow-derived endothelial progenitor cells. Arterioscler Thromb Vasc Biol 2009; 29: 1179-1184

24. Poon RT-P, Ng IO-L, Lau C I wsp. Serum vascular endothelial growth factor predicts venous invasion in hepatocellular carcinoma: a prospective study. Annal of Surg 2001; 233: 227-235.

25. Tanaka S, Sugimachi K, Yamashita Yi I wsp. Tie2 vascular endothelial receptor expression and function in hepatocellular carcinoma. Hepatology 2002; 35:861-867.

26. Mathonnet M, Descottes B, Valleix D i wsp. VEGF in hepatocellular carcinoma and surrounding cirrhotic liver tissue. World J Gastroenterol 2006; 12: 830-831.

27. Ziegler BL, Valtieri M, Porada GA i wsp. KDR receptor: a key marker defining hematopoietic stem cells. Science 1999; 285: 1553-1555.
28. Schmitt $\mathrm{M}$, Horbach $\mathrm{A}$, Kubitz $\mathrm{R}$ i wsp. Disruption of hepatocellular tight junctions by vascular endothelial growth factor (VEGF): a novel mechanism for tumor invasion. J Hepatol 2004; 41: 274-283.

29. Hiratsuka S, Watanabe A, Aburatani Hiwsp. Tumourmediated upregulation of chemoattractants and recruitment of myeloid cells predetermines lung metastasis. Nat Cell Biol 2006; 8: 1369-1375.

30. Arii S. Role of vascular endothelial growth factor on the invasive potential of hepatocellular carcinoma. J Hepatol 2004; 41:333-335.

31. Lingala S, Cui Y-Y, Chen X I wsp. Immunohistochemical staining of cancer stem cell markers in hepatocellular carcinoma. Experimental and Molecular Pathology 2010; 89: 27-35 .

32. Khan SS, Solomon MA, McCoy Jr JP. Detection of circulating endothelia cells and endothelial progenitor cells by flow cytometry. Cytometry $B$ Clin Cytom 2005; 64: 1-8.

33. Fina L, Molgaard HV, Robertson D i wsp. Expression of the CD34 gene in vascular endothelial cells. Blood 1990; 75: 2417-2426.

34. Yin AH, Miraglia S, Zanjani ED i wsp. AC133, a novel marker for human hematopoietic stem and progenitor cells. Blood 1997; 90: 5002-5012.

35. Król M, Urbanowska E, Feliksbrot M i wsp. Phenotype characteristic CD34+ cells from umbilical cord-derived blood and products of leucaferesis in stimulated healthy donors. Adv Clin Exp Med. 2005; 14: 877-884.

36. Case J, Haneline LS, Yoder MC i wsp. Reply to Fadini et al: Critical assessment of putative endothelial progenitor phenotypes. Exp Hematol 2007; 35: 1481-1482.

37. Fadini GP, de Kreutzenberg SV, Coracina A i wsp. Circulating CD34+ cells, metabolic syndrome, and cardiovascular risk. Eur Heart J 2006; 27: 2247-2255.

38. Fadini GP, Baesso I, Albiero M i wsp. Technical notes on endothelial progenitor cells: Ways to escape from the knowledge plateau. Atherosclerosis 2008; 197: 496-503.

39. Friedrich EB, Walenta K, Scharlau J i wsp. A CD34-/CD133+/VEGFR-2+ endothelial progenitor cell subpopulation with potent vasoregenerative capacities. Circ Res 2006; 98: e20-25.

40. Blann AD, Pretorius A. Circulating endothelial cells and endothelial progenitor cells: two sides of the same coin, or two different coins? Atherosclerosis 2006; 188: 12-18.

41. Baumgarth N, Roederer M. A practical approach to multicolor flow cytometry for immunophenotyping. J/mmuno/Methods 2000;243:77-97.

42. Perfetto SP, Chattopadhyay PK, Roederer M. Seventeen-colour flow cytometry: Unraveling the immune system. Nature Rev 2004; 4: 648-655.

43. Miller-Kasprzak E, Jagodziński PP. Endothelial progenitor cells as a new agent contributing to vascular repair. Arch Immmunol Ther Exp 2007; 55: $247-259$.

44. Sieghart W, Fellner S, Reiberger T i wsp. Differential role of circulating endothelial progenitor cells in cirrhotic patients with or without hepatocellular carcinoma. Dig Liver Dis 2009; 41: 902-906.

45. Ho JWY, Pang RWC, Lau C I wsp. Significance of circulating endothelial progenitor cells in hepatocellular carcinoma. Hepatology 2006; 44: 836-845.

46. Mas VR, Maluf DG, Archer KJ i wsp. Angiogenesis soluble factors as hepatocellular carcinoma noninvasive markers for monitoring hepatitis $C$ virus cirrhotic patients awaiting liver transplantation. Transplantation 2007; 84: 1262-1271.

47. Chih-Hung Chen, Li-Teh Chang, Wei-Chih Tung i wsp. Levels and values of circulating endothelial progenitor cells, soluble angiogenic factors, and mononuclear cell apoptosis in liver cirrhosis patients. J Biomedical Science 2012; 19: 66-77.

48. Guirouilh J, Le Bail B, Boussarie L. Expression of hepatocyte growth factor in human hepatocellular carcinoma. J Hepatol 2001:34:78-83.

49. Beerepoot LV, Mehra N, Vermaat JS i wsp. Increased levels of viable circulating endothelial cells are an indicator of progressive disease in cancer patients. Ann Oncol 2004; 15: 139-145

50. Ding YT, Kumar S, Yu DC. The role of endothelial progenitor cells in tumor vasculogenesis. Pathobiology 2006; 75: 265-273.

51. Kim HK, Song KS, Kim HO i wsp. Circulating numbers of endothelia progenitor cells in patients with gastric cancer and brest cancer. Cancer Lett 2003; 198: 83-88.

52. Gadelhak NA, Gadelhak SA, El-Morsi DA i wsp. Prognostic significance of three hepatitis markers (p53 antibodies, vascular endothelial growth factors and alfa-fetoprotein) in patients with hepatocellular carcinoma. Hepatogastroenterology 2009; 56: 1417-1424. 